\title{
Dependence of public health on energy consumption: a cross-regional analysis
}

\author{
Nataliia Letunovska ${ }^{1}$, Liudmyla Saher ${ }^{1 *}$, Tetiana Vasylieva $^{2}$, and Serhiy Lieonov ${ }^{3}$ \\ ${ }^{1}$ Department of Marketing, Academic and Scientific Institute of Business, Economics and \\ Management, Sumy State University, 2, Rymskogo-Korsakova st., 40007 Sumy, Ukraine \\ ${ }^{2}$ Head of Academic and Scientific Institute of Business, Economics and Management, Sumy State \\ University, 2, Rymskogo-Korsakova st., 40007 Sumy, Ukraine \\ ${ }^{3}$ First Vice-rector of Sumy State University, 2, Rymskogo-Korsakova st., 40007 Sumy, Ukraine
}

\begin{abstract}
The authors test the hypothesis that there is a link between the consumption of non-renewable resources of the leading economies in the European region in terms of value-added industry and health. They performed a ranking correlation analysis on key indicators of population health and volumes of consumption of renewable and non-renewable resources in individual countries. The researchers assumed a slight relationship between the rate of healthy years of life and the production of renewable energy resources, making a positive contribution to the country's environmental situation. Among the compared countries, those characterized by high consumption of primary energy resources are proportionally more productive and renewable energy resources. The analysis shows that differences in the health indicators of the regions' population cause other more important factors than the studied ones. Some dependencies can be seen in analyzing the causes of death among the population of countries, for example, by cardiovascular diseases. The risk factor for this illness is air pollution caused by excessive consumption of non-renewable energy resources. The authors recommend considering the indicator of ecological footprint in the ratings of life quality in the regions. Compared to countries with lower welfare rankings, this parameter is too high for leaders. Under investigation, the authors considered the $\mathrm{x} 3$ weight for the health indicator in the Legatum Prosperity Index.
\end{abstract}

\section{Introduction}

Health is an integral indicator of the success of the development of the world community. It is an inalienable right of every human being and an essential component of well-being. Under the current conditions of the COVID-19 pandemic, humanity needs to provide an uninterrupted power supply as never before. After all, the enormous efforts of medical personnel worldwide depend on electrical equipment, which is vital to enable people to overcome the disease. Achieving high-quality public health is possible by eliminating risk

\footnotetext{
${ }^{*}$ Corresponding author: lyudmila.sager@gmail.com
} 
factors. Risk factors create a negative background that contributes to disease. The risk factor is environmental pollution. The unity and struggle of opposites in the context of public health determines the use of energy resources - non-renewable and renewable sources, which ultimately determines the state of a particular region's environment. When to increase the effectiveness of sustainable development policy, there is a complex dilemma when society needs to spend a significant amount of energy resources on maintaining a decent standard of living in the country. Simultaneously, to preserve the environment, it is appropriate to limit the consumption of energy resources as much as possible. A comparison of existing approaches to assessing the quality of life of the population of a particular region showed that the set of parameters of the country's ecological state and public health considers the method of calculating The Legatum Prosperity Index. Such standard methods of assessing the quality of life as the Human Development Index and the International Happiness Index do not consider the energy factor.

Bibliometric analysis $[1,2]$ showed a significant interest in the research question. The review of 1211 publications from the Scopus database (1992-2020) was conducted. Three combinations of words with the logical operator ("health" AND "renewable energy" AND "energy consumptions") were used. The "title, abstract, keywords" field of search in the Scopus database was done. The visualization of the results was made using VOSviewer program to graphically map the material. The Scopus screening tools showed that in 2009 the number of articles that focused on public health and energy consumption began to increase. Using the VOS viewer program were identified the main 7 clusters of the scientific papers (Fig. 1).

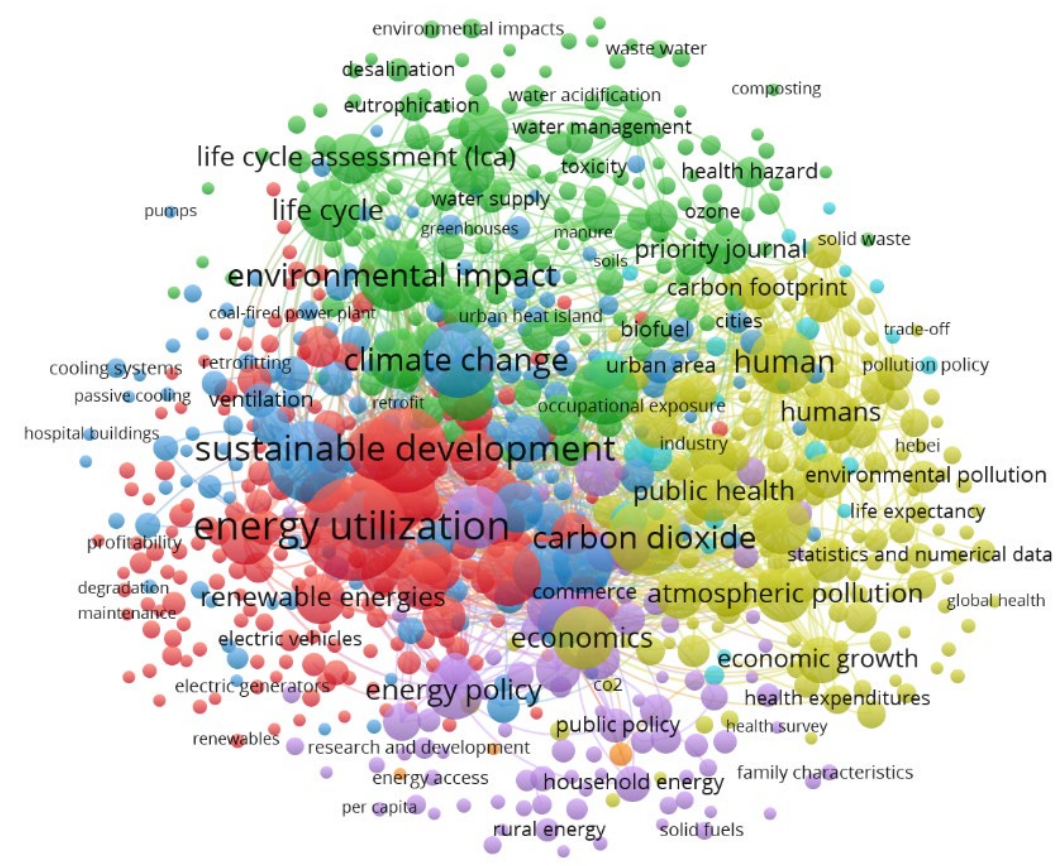

Fig. 1. The results of network relationships analysis of the key categories in scientific publications on (composed by the authors using VOSviewer 1.6.16)

Thus, the analysis showed the existence of the four most important conditional clusters related to the categories "energy utilization", "environmental impact", "carbon dioxide". The first (red) cluster "energy utilization" (occurrences - 299, total link strength - 3834) includes such basic concepts: "sustainable development", "health", "renewable energy", "health risks", 
"fossil fuels". Second (green) cluster "environmental impact" (occurrences - 147, total link strength - 2158) includes such basic concepts: "energy consumption", "life cycle assessment", "life cycle", "life cycle analysis". The third main (blue) cluster "energy efficiency" (occurrences - 180, total link strength - 2175) includes such basic concepts: "climate change", "energy use", "air quality", "indoor air pollution". Yellow cluster "carbon dioxide" (occurrences - 162, total link strength - 2691) includes such basic concepts: "human", "air pollution", "economics", atmospheric pollution".

The analysis results show the closeness of the concepts of "health", "environment", "energy", "pollution", "life cycle", "economy", which once again confirms the relationship between the use of renewable or non-renewable energy resources and the environment, life expectancy, as well as the overall development of the country's economy, which is also associated with available resources and human health characteristics.

On the international level, the investigated area was represented by the next countries: China, United Kingdom, the United States, India, Pakistan, Italy [3-6].

Among Ukrainian scientists [7-13], issues of environmental, economic, energy and social security are also widely studied. In [14-18] the main aspects of environmental, communication management are identified, the analysis of marketing tools that serve as a tool for interaction with energy consumers and other participants in the energy market and health care. Researchers [19-27] actively analyze the issues of public administration, instruments of influence on the region's development, the country's development, provide key parameters of the country's development and the main factors of influence, ecologic startups. Innovations in the energy market, the relationship between renewable energy and energy efficiency, the state of smart grids implementation and the role of stakeholders in this process, including cross-regional, are discussed in the following studies [28-30]. The authors [31-38] also consider the relationship between the effects of the COVID-19 pandemic and public health and economic growth, the reasons for the differentiation of morbidity in the regional context, search for factors of economic vulnerability. The authors [39-40] consider energy management from the standpoint of efficiency in the field of green investment

The study aims to determine the dependence of public health on the growth of consumption of such energy resources as renewable instead of non-renewable energy resources in different national economies and determine the environmental impact of different world regions.

\section{Materials and methods}

The authors used the European structural indicator Healthy life years expectancy (HALE) (the number of years that a person will continue to live in a healthy condition) as the initial comparable public health level parameter. In other words, it is the number of healthy years that a newborn will live in the country, taking into account the disease. Besides, they included Disability-adjusted life year (DALY) as an indicator of lost years of life due to disease. One point of this indicator is equal to one lost year of a person's life. During the correlation analysis, the relationship between these indicators will be inversely proportional.

Comparative research (to compare the characteristics of national economies in the investigated field) and mathematical statistics (correlation analysis using the software Statistica 10 Version) were used. The basis of the study is national data and data of international organizations on the measured indicators.

The authors formed several hypotheses of the study:

H1: The DALY indicator is higher and the HALE indicator is lower in the regions with significant non-renewable energy consumption. 
$\mathrm{H} 2$ : Countries with higher non-renewable energy resources tend to have proportionally higher values of renewable energy production.

H3: The economies of higher welfare countries leave a larger ecological footprint than countries with lower welfare rates.

The researchers performed several iterations to confirm or refute them.

\section{Empirical model}

To check the absence of a statistically significant correlation between the analyzed parameters, the authors check the formula:

$$
\mathrm{H}: \tau_{k j}^{S}=0
$$

The proof is accepted at the level of significance $\alpha$, if:

$$
\mathrm{t}=\frac{\hat{\tau}_{k j}^{S}}{\sqrt{1-\left(\hat{\tau}_{k j}^{S}\right)^{2}}} \sqrt{n-2}<t_{\gamma, f},
$$

where $t_{\gamma, f}-$ threshold value of the Student's distribution with parameters $\gamma=1-\alpha / 2$, $f=n-2$. Otherwise, the evidence is not confirmed.

\section{Results and discussions}

An essential indicator of the competitiveness of the national economy is GDP. Capital Times [41], a finance and investment consultant, analyzed the structure of Ukraine's GDP in the dynamics in terms of economic sectors with projected values for 2022. The processing industry is one of the most energy-intensive sectors of Ukraine's economy. According to the forecasts of the Capital Times, a high share of the processing industry will remain. Figure 2 shows the contribution of sectors to GDP by 2022.

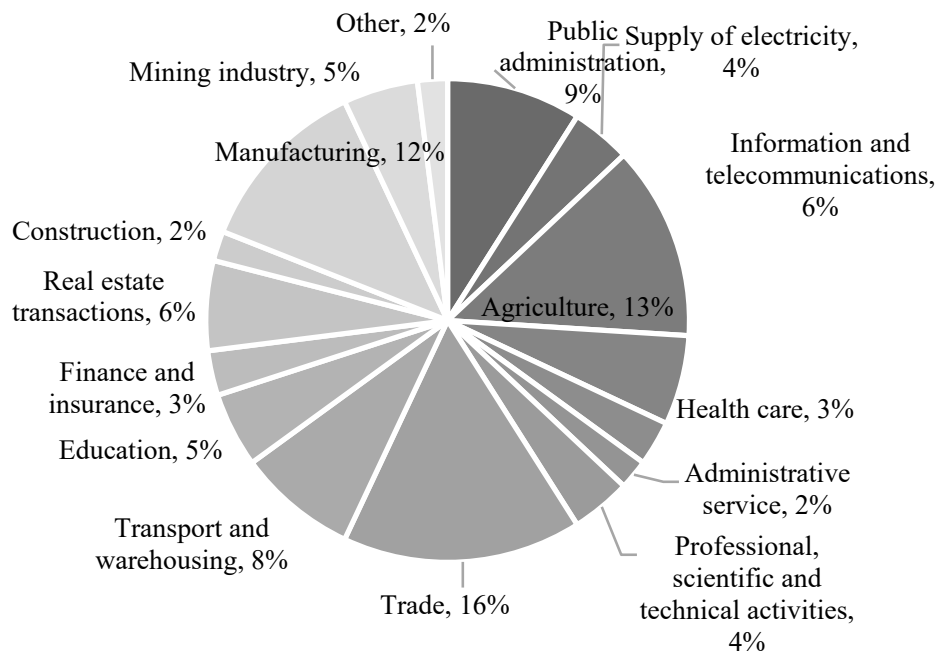

Fig. 2. Forecast structure of Ukraine's GDP until 2022 (developed using [41]) 
Ukraine has a high energy intensity of GDP, which indicates the need for significant reforms to reduce energy consumption. One of the effective ways to replace primary energy resources is their gradual partial replacement with renewable energy sources. The authors decided to compare Ukraine with the European region countries, in which production also plays a significant role in the economy. Table 1 demonstrates the results of analyzing indicators of the manufacturing sector of the European region.

Table 1. Key indicators of manufacturing of the countries of the European region in 2017 (formed using [42])

\begin{tabular}{|c|c|c|c|c|}
\hline \multirow[t]{2}{*}{ Country } & $\begin{array}{l}\text { Number of } \\
\text { enterprises }\end{array}$ & $\begin{array}{c}\text { Number of persons } \\
\text { employed }\end{array}$ & Turnover & Value added \\
\hline & \multicolumn{2}{|r|}{ thousands } & \multicolumn{2}{|c|}{ EUR million } \\
\hline Germany & 190.5 & $7,409.6$ & $2,193,357.5$ & $592,027.2$ \\
\hline Italy & 383.6 & $3,744.3$ & 965,031 & $241,413.9$ \\
\hline France & 197.7 & $3,103.6$ & $1,021,247.9$ & $240,268.1$ \\
\hline Spain & 168.7 & 1917.7 & $505,350.9$ & $110,841.4$ \\
\hline $\begin{array}{l}\text { United } \\
\text { Kingdom }\end{array}$ & 136.7 & $2,556.4$ & $700,030.8$ & 102,841 \\
\hline Ireland & 16.7 & 219.8 & $226,192.9$ & $97,262.2$ \\
\hline Netherlands & 66.7 & 698.5 & $345,979.9$ & $70,850.4$ \\
\hline Switzerland & 20.1 & 656.7 & $298,061.2$ & $57,276.1$ \\
\hline Belgium & 36.8 & 500.8 & $267,652.4$ & $56,092.4$ \\
\hline $\begin{array}{l}\text { Czech } \\
\text { Republic }\end{array}$ & 175.9 & 1319.4 & $178,105.9$ & $39,930.5$ \\
\hline Austria & 25.5 & 638.6 & $191,203.9$ & $35,641.8$ \\
\hline Denmark & 15.3 & 310.4 & $115,938.8$ & $35,623.4$ \\
\hline Sweden & 53.7 & 610.2 & $213,355.3$ & $35,480.7$ \\
\hline Poland & 198.8 & $2,654.8$ & $321,925.9$ & $34,119.7$ \\
\hline Hungary & 50.8 & 757.8 & $109,581.7$ & 24,176 \\
\hline Finland & 20.2 & 332.9 & $123,675.7$ & $16,890.3$ \\
\hline Norway & 17.0 & 221.9 & 85,695 & $14,658.6$ \\
\hline Portugal & 67.6 & 711.7 & $90,310.8$ & $12,402.2$ \\
\hline Romania & 49.8 & $1,215.9$ & $83,852.6$ & $11,707.5$ \\
\hline Greece & 57.4 & 320.5 & $54,119.8$ & $11,521.2$ \\
\hline Slovakia & 72.6 & 501.3 & $76,382.2$ & $7,900.2$ \\
\hline Bulgaria & 31.3 & 556.1 & $33,370.8$ & $7,767.2$ \\
\hline Croatia & 19.5 & 268.7 & $21,497.5$ & $6,126.4$ \\
\hline Slovenia & 19.4 & 204.9 & 29,353 & $4,940.2$ \\
\hline Lithuania & 20.3 & 216.5 & $20,257.7$ & $4,552.7$ \\
\hline Luxemburg & 0.8 & 34.1 & 13,703 & $3,125.2$ \\
\hline Estonia & 7.5 & 110.1 & $12,474.7$ & $3,018.2$ \\
\hline Latvia & 10.9 & 119.5 & 8,409 & $2,333.9$ \\
\hline Cyprus & 5.0 & 31.9 & $3,411.4$ & $1,077.6$ \\
\hline Iceland & 2.1 & 22.8 & $6,566.6$ & $1,552.4$ \\
\hline
\end{tabular}

The authors sorted the analyzed countries by value added of the sphere of production in the economy and singled out countries with the most significant manufacturing industry contribution. These countries are Germany, Italy, France, Spain, United Kingdom, Ireland, Netherlands, Switzerland, Belgium, Czech Republic. Then it is appropriate to compare some countries with Ukraine in terms of research parameters to confirm or refute the author's hypotheses (Table 2). 
Table 2. Researched indicators by country in 2019 (formed using [43-46])

\begin{tabular}{|l|c|c|c|c|}
\hline Country & $\begin{array}{c}\text { Primary energy } \\
\text { Supply } \\
\text { (non-renewable), ktoe }\end{array}$ & $\begin{array}{c}\text { DALY, } \\
\text { Years }\end{array}$ & $\begin{array}{c}\text { Renewable } \\
\text { energy generation, GWh }\end{array}$ & Healthy life years, years \\
\hline Germany & 235,833 & 20,075 & 199,889 & 69.5 \\
\hline Italy & 116,269 & 18,648 & 97,464 & 71.2 \\
\hline France & 114,736 & 18,782 & 108,142 & 71.3 \\
\hline Spain & 87,673 & 17,086 & 97,438 & 68.9 \\
\hline $\begin{array}{l}\text { United } \\
\text { Kingdom }\end{array}$ & 132,694 & 20,957 & 84,526 & 70.1 \\
\hline Ireland & 11,784 & 10,755 & 10,553 & 70.4 \\
\hline Netherlands & 63,733 & 18,888 & 16,667 & 69.7 \\
\hline Switzerland & 11,571 & 17,635 & 43,073 & 68.5 \\
\hline Belgium & 38,866 & 20,170 & 14,673 & 61.7 \\
\hline $\begin{array}{l}\text { Czech } \\
\text { Republic }\end{array}$ & 30,839 & 21 & 6,161 & \\
\hline Ukraine & 67,033 & 34,975 & 10,225 & \\
\hline
\end{tabular}

The correlation analysis results (Table 3) show that the relationship between the variables on the consumption of renewable and non-renewable energy resources is statistically significant. That is, highly energy-intensive countries tend to consume more of both types of resources. It is essential that, in the long run, renewable energy resources predominate in such regions' energy consumption [47]. One can hypothesize a link between healthy life expectancy and renewable energy production in a country (the higher the production, the potentially better the state of the environment, and naturally, the population's state of health).

Table 3. The results of correlation analysis of the initial parameters of the study

\begin{tabular}{|c|c|c|c|c|}
\hline \multicolumn{5}{|c|}{$\begin{array}{l}\text { Spearman Rank Order Correlations (Spreadsheet1) MD pairwise deleted Marked correlations ar } \\
\text { significant at } \mathrm{p}<, 05000\end{array}$} \\
\hline & $\begin{array}{c}\text { Primary } \\
\text { energy supply }\end{array}$ & DALY & $\begin{array}{l}\text { Renewable energy } \\
\text { generation }\end{array}$ & HALE \\
\hline $\begin{array}{c}\text { Primary energy } \\
\text { supply }\end{array}$ & 1,000000 & 0,218182 & 0,727273 & $-0,132119$ \\
\hline DALY & 0,218182 & 1,000000 & $-0,354545$ & $-0,842827$ \\
\hline $\begin{array}{l}\text { Renewable } \\
\text { energy } \\
\text { generation }\end{array}$ & 0,727273 & $-0,354545$ & 1,000000 & 0,523919 \\
\hline HALE & $-0,132119$ & $-0,842827$ & 0,523919 & 1,000000 \\
\hline
\end{tabular}

Figure 3 shows the results of the calculation to test this assumption. The figure proves that a significant relationship between these parameters did not come true ( $p$-value in the pair Renewable energy generation \& HALE is less than the accepted norm of 0.05).

The authors assumed that the dependencies would be in the case of structural analysis of the causes of reduced years of healthy life due to various diseases, in particular, due to cardiovascular diseases, which are significant due to possible adverse effects of the adverse environment (Fig. 3).

For countries with significant consumption of non-renewable energy resources (Germany, United Kingdom), the DALY indicator for this type of disease is higher than countries where these energy resources' consumption is low. 


\begin{tabular}{|c|c|c|c|c|}
\hline \multirow[b]{2}{*}{ Pair of Variables } & \multicolumn{4}{|c|}{$\begin{array}{l}\text { Spearman Rank Order Correlations (Spreadsheet } 1 \\
\text { MD pairwise deleted } \\
\text { Marked correlations are significant at } p<, 05000\end{array}$} \\
\hline & \begin{tabular}{|c|} 
Valid \\
$\mathrm{N}$
\end{tabular} & $\begin{array}{c}\text { Spearman } \\
\mathrm{R}\end{array}$ & $t(\mathrm{~N}-2)$ & p-value \\
\hline \multicolumn{5}{|l|}{ Primary energy supply \& Primary energy supply } \\
\hline Primary energy supply \& DALY & 11 & 0,218182 & 0,67070 & 0,519248 \\
\hline Primary energy supply \& Renewable energy generation & 11 & 0,727273 & 3,17888 & 0,011205 \\
\hline Primary energy supply \& HALE & 11 & $-0,132119$ & $-0,39986$ & 0,698582 \\
\hline DALY \& Primary energy supply & 11 & 0,218182 & 0,67070 & 0,519248 \\
\hline \multicolumn{5}{|l|}{ DALY \& DALY } \\
\hline DALY \& Renewable energy generation & 11 & $-0,354545$ & $-1,13753$ & 0,284693 \\
\hline DALY \& HALE & 11 & $-0,842827$ & $-4,69816$ & 0,001123 \\
\hline Renewable energy generation \& Primary energy supply & 11 & 0,727273 & 3,17888 & 0,011205 \\
\hline Renewable energy generation \& DALY & 11 & $-0,354545$ & $-1,13753$ & 0,284693 \\
\hline \multicolumn{5}{|c|}{ Renewable energy generation \& Renewable energy generation } \\
\hline Renewable energy generation \& HALE & 11 & 0,523919 & 1,84529 & 0,098083 \\
\hline HALE \& Primary energy supply & 11 & $-0,132119$ & $-0,39986$ & 0,698582 \\
\hline HALE \& DALY & 11 & $-0,842827$ & $-4,69816$ & 0,001123 \\
\hline HALE \& Renewable energy generation & 11 & 0,523919 & 1,84529 & 0,098083 \\
\hline HALE \& HALE & & & & \\
\hline
\end{tabular}

Fig.3. In-depth analysis of comparable indicators by the p-value criterion

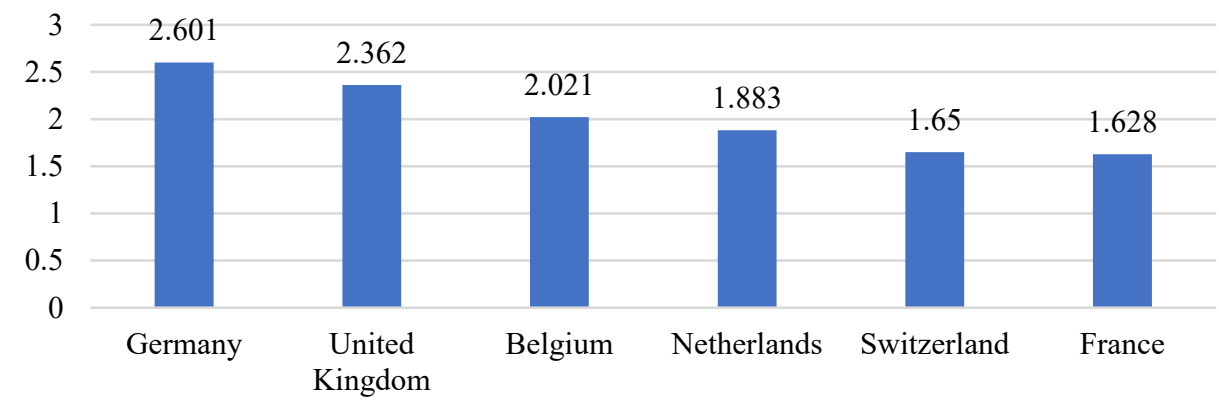

Fig. 4. Add rate of DALY due to cardiovascular diseases, per 100,000 population in 2019 (based on [46])

Another comparison of two parameters will help formulate a vision on energy consumption, environmental conditions and regional indicators of quality of life. Figure 5 demonstrates the map of the ratio of the leading countries' positions in the ranking of The Legatum Prosperity Index and countries at the lower levels of the rank. The pairwise construction of the map is relative to the second important indicator - Ecological Footprint. The welfare ranking has manually removed environmental indicators and added $\mathrm{x} 3$ weight to the region's health component.

The map shows that the Legatum Prosperity Index's best positions do not mean that the country is frugal in consumer products, including energy, and careful in waste management. The authors suggest paying more attention to the indicators of lean energy consumption, particularly the use of renewable energy sources. The future in the direction of development of the region in a healthy vector includes such ratings of human development ecological footprint. 


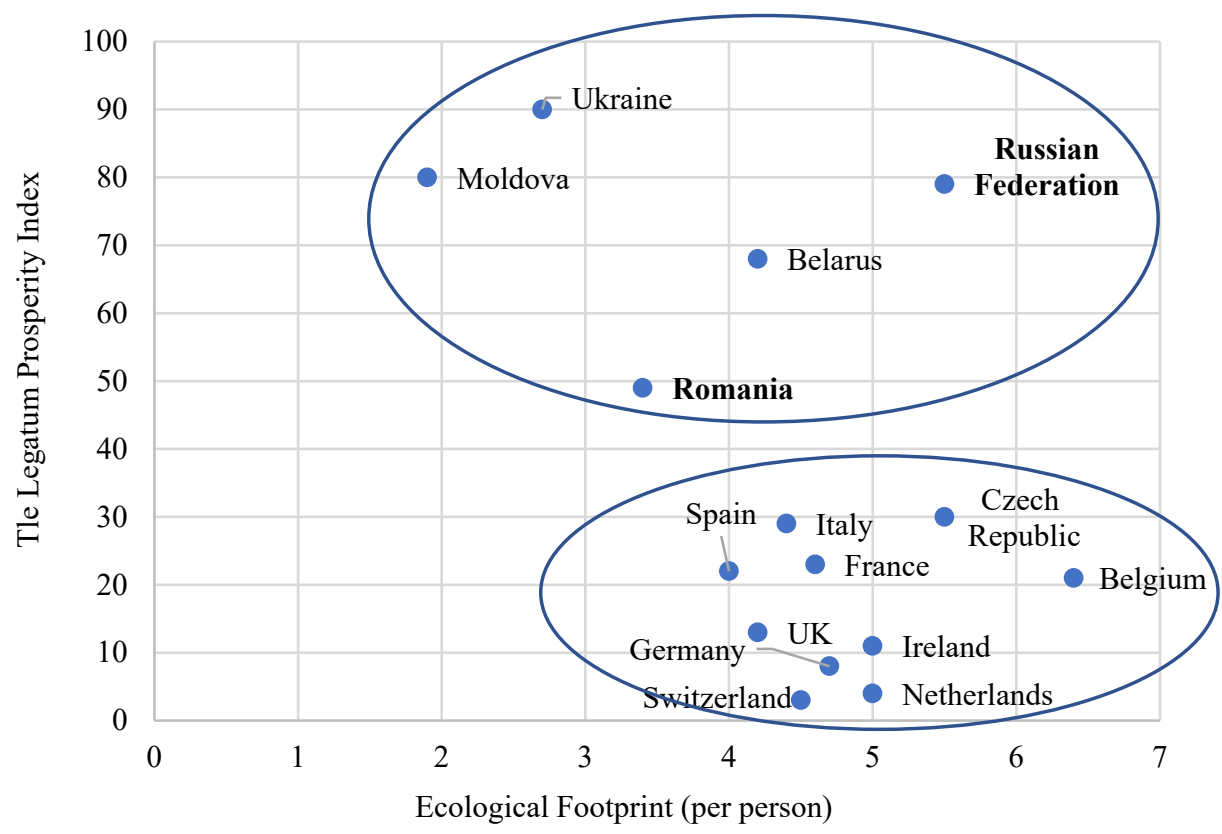

Fig. 5. Map comparing countries in The Legatum Prosperity Index with the national ecological footprint (built using [48-49])

\section{Conclusions}

The hypotheses of the authors after the study were partially confirmed. The hypothesis of DALY and HALE indicators' dependence is directly proportional and inversely proportional, respectively, was not confirmed. The results refuted the hypothesis about a relationship. However, the researchers confirmed the hypothesis that countries with higher rates of non-renewable energy use are also producers of higher amounts of renewable energy sources. It is due to the need for production capacity and economies' focus on achieving sustainable development goals. A comparative analysis has not confirmed that countries with higher welfare have a smaller environmental footprint worldwide. The authors proposed to thoroughly approach the assessment in the framework of human development ratings considering the environmental impact parameters from excessive consumption of nonrenewable resources. Prospects for further research are the search for a neutral index that will consider both those indicators that already exist in calculating the quality of life and welfare of the population of individual regions and those that indicate positive changes in society in promoting renewable energy sources.

\section{Acknowledgment}

The National Research Foundation of Ukraine supported this work (the project No. 0120U104807 "Stochastic modelling of road map for harmonizing national and European standards for energy market regulation in the transition to a circular and carbonfree economy"). 


\section{References}

1. H. Dzwigol, M. Dzwigol-Barosz. Academy of Strategic Management Journal, 19(5), 1-7 (2020).

2. L. Khomenko, L. Saher, K. Polcyn. Health Economics and Management Review, 1, 20$36(2020)$.

3. J. Lusk, A. Mook. SocioEconomic Challenges, 4(3), 33-45 (2020).

4. Bhandari P. Medani. SocioEconomic Challenges, 3(4), 97-128 (2019).

5. J. Yelnikova, A. Kwilinski. Business Ethics and Leadership, 4(3), 57-64 (2020).

6. A. Karaoulanis. Business Ethics and Leadership, 2(4), 108-114 (2018).

7. Y. Samusevych, A. Vysochyna, T. Vasylieva, S. Lyeonov, S. Pokhylko. E3S Web of Conferences, 234, 00012 (2021)

8. L. F. Sokolenko, I. V. Tiutiunyk, D. V. Leus. International Journal of Ecology and Development, 32(3), 27-35 (2017).

9. R. Miskiewicz. Energies, 13(22), 6106 (2020)

10. R. Miskiewicz Polityka Energetyczna, 21(2), 49-62 (2018)

11. T. Vasilyeva, O. Kuzmenko, V. Bozhenko, O. Kolotilina, CEUR Workshop Proceedings, 2422 134-146 (2019).

12. K. Djalilov, S. Lyeonov, A. Buriak. Risk Governance and Control: Financial Markets and Institutions, 5(4CONT1), 178-187 (2015)

13. Y. Kharazishvili, A. Kwilinski, O. Grishnova, H. Dzwigol, Sustainability, 12(21), 8953 (2020)

14. O. Lyulyov, T. Pimonenko, A. Kwilinski, H. Dzwigol, M. Dzwigol-Barosz, V. Pavlyk, P. Barosz. Energies, 14(2), 373 (2021)

15. A. Teletov, S. Teletova, N. Letunovska. Periodicals of Engineering and Natural Sciences, 7 (2), 458-465 (2019)

16. O. Bilovodska, O. Gryshchenko, L. Syhyda, Economic Annals-XXI, 160(7-8), 105-110 (2016)

17. L. Syhyda. Economic Annals-XXI, 7-8(2), 28-32 (2013)

18. A. Rosokhata, O. Rybina, A. Derykolenko, V. Makerska. Research in World Economy, 11(4), 42-52 (2020).

19. O. Tulai, Y. Petrushenko, J. Glova, I. Sydor, O. Ponomarenko, Investment Management and Financial Innovations, 16(4), 1-15 (2019)

20. O. Lyulyov, H. Shvindina. Problems and Perspectives in Management, 15(3), 42-52 (2017)

21. Y. Bilan, I. Tiutiunyk, S. Lyeonov, T. Vasylieva. International Journal of Economic Policy in Emerging Economies, 13(2), 173-193 (2020)

22. B. A. Alyobi, I. M. Alharbi, A. A. Qaffas, N. K. Almazmomi, Marketing and Management of Innovations, 2, 247-255 (2020)

23. A. El Amri, R. Boutti, S. Oulfarsi, F. Rodhain, B. Bouzahir, Financial Markets, Institutions and Risks, 4(4), 31-44 (2020).

24. R. Abeysekera, Financial Markets, Institutions and Risks, 4(2), 43-51 (2020)

25. I. Wieland, L. Kovács, T. Savchenko, Financial Markets, Institutions and Risks, 4(1), 51-59 (2020)

26. M. Dove, A. Balasubramanian, B.G. Narayanan, SocioEconomic Challenges, 4(4), 48$62(2020)$

27. I. Makarenko, N. Sirkovska, Business Ethics and Leadership, 1(1), 16-24 (2017)

28. S. Kolosok, I. Myroshnychenko, H. Mishenina, I. Yarova, E3S Web of Conferences, 234, 00021 (2021) 
29. I. Vakulenko, L. Saher, L. Syhyda, S. Kolosok, A. Yevdokymova, E3S Web of Conferences, 234, 00020 (2021)

30. O. Prokopenko, J. Cebula, S. Chayen, T. Pimonenko, International Journal of Ecology and Development, 32(1), 98-107 (2017)

31. O. Kuzmenko, T. Vasylieva, S. Vojtovič, O. Chygryn, V. Snieška, Spatial nonlinear modeling of social and economic patterns. Economics and Sociology, 13(4), 318-340 (2020)

32. V. A. Smiianov, O. V. Lyulyov, T. V. Pimonenko, T. A. Andrushchenko, S. Sova, N. V. Grechkovskaya. Wiadomosci Lekarskie, 73(11), 2332-2338 (2020)

33. V. A. Smiianov, T. A. Vasilyeva, O. Y. Chygryn, P. M. Rubanov, T. M. Mayboroda, Wiadomosci Lekarskie, 73(10), 2181-2187(2020).

34. Ya. Us, T. Pimonenko, T. Tambovceva, J-P. Segers, Health Economics and Management Review, 1(1), 48-59. (2020)

35. F. Rahmanov, R. Aliyeva, A. Rosokhata, N. Letunovska, Marketing and Management of Innovations, 3, 195-207 (2020)

36. R. Vanickova, Marketing and Management of Innovations, 2, 56-67 (2020)

37. L. Lesakova, Marketing and Management of Innovations, 3, 89-97. (2019)

38. Ye. Ziabina, T. Pimonenko, L. Starchenko. SocioEconomic Challenges, 4(4), 160-174 (2020)

39. V. Pavlyk, Financial Markets, Institutions and Risks, 4(1), 117-123 (2020)

40. L. Yiu, R. Saner, R. Bardy, Business Ethics and Leadership, 4(4), 14-27 (2020)

41. The Capital Times, https://www.capital-times.com/ua-ua/analysis-of-ukraines-gdpdynamics (2019)

42. Manufacturing Statistics, explained/pdfscache/10086.pdf(2020)

43. International Energy Agency, https://www.iea.org/data-andstatistics? country $=U K R A I N E \&$ fuel $=$ Energy $\% 20$ supply\&indicator $=$ RenewGenBySour ce (2021)

44. Country profiles of Environmental Burden of Disease, https://www.who.int/quantifying_ehimpacts/national/countryprofile/czechrepublic.pdf? $u a=1(2021)$

45. Peterson-KFF. Health System Tracker, https://www.healthsystemtracker.org/indicator/health-well-being/disability-adjustedlife-years/ (2021)

46. Global Health Metrics, https://www.thelancet.com/action/showPdf?pii=S01406736\%2820\%2930977-6 (2020)

47. R. Skrynkovskyy, A. Kataiev, O. Zaiats, H. Andrushchenko, N. Popova, Journal of Optimization in Industrial Engineering, 14(1), 103-110. (2021)

48. The Legatum Prosperity Index 2020, https://www.prosperity.com/rankings? pinned $=\&$ filter $=.(2021)$

49. Ecological footprint of European countries, https://www.eea.europa.eu/data-andmaps/indicators/ecological-footprint-of-european-countries-2/assessment (2021) 